\title{
Value of Public Administration Management to International Relations: Scaffolding an Inter-Disciplinary Research Agenda
}

\author{
Phua Chao Rong, Charles \\ Ministry of Defence, Singapore, Singapore \\ Lee Kuan Yew School of Public Policy (LKYSPP), Singapore, Singapore
}

\begin{abstract}
Both Public Administration and Management (PAM) and International Relations (IR) was founded as a discipline in the inter-war period (between First and Second World Wars). Incidentally, Woodrow Wilson was a key figure in the theory and praxis for both disciplines. However, since then, the study of PAM and IR were separated in substance in what was called the "great divide" in IR, the presumption that domestic and international politics are distinct spheres that are defined by distinct organizing principles. Today, this "great divide" is being challenged with globalization. However, the attempt of looking at the domestic aspects of IR and international aspects of PAM stopped short of a deep inter-disciplinary discourse. Apart from labeling its international/global version of PAM and vice versa, the scope and objectives of this inter-discipline has been under-theorized. IR can be conceptually defined as how international affairs work while PAM as how [domestic] public affairs work. As such, both can be seen as applied social and policy sciences aimed at tackling public problems at different levels (international, regional and national/domestic). There are at least two complementary ways to build this inter-disciplinary discourse: (1) what can IR offer PAM; (2) what can PAM offer IR, before a research synthesis (Harris, 2010) effort to consolidate the similarities, differences and interesting aspects in order to lay a coherent foundation of PAM-IR inter-discipline. For reasons of scope and space, this essay attempts to explore the latter research question. PAM will be broadly defined as a discipline that includes sub-fields of PAM theory, Public Policy (PP) Process, Economics, and Political-Economy of Public Policy, amongst others. In each PAM sub-field, similarities, differences, possible overlaps with and potential intellectual borrowing for IR will be discussed.
\end{abstract}

Keywords: complexity thinking, international relations, public administration, public policy, international public policy, conceptual frameworks

\section{Introduction}

Both Public Administration and Management (PAM) and International Relations (IR) was founded as a discipline in the inter-war period (between First and Second World Wars). Incidentally, Woodrow Wilson was a key figure in the theory and praxis for both disciplines. Woodrow Wilson's seminal article in 1887 can be considered the first work in modern PAM, before Leonard D. White's arguably first PAM textbook in 1926 (Wilson, 1887; White, 1926, pp. 49-56). In IR, the UK started the first IR department at University of Aberystwyth in 1919 with a gift of $£ 20,000$ by David Davies. Davies' gift also supported the establishment of

Phua Chao Rong, Charles, Head Research Trainer, Ministry of Defence; Lee Kong Chian Graduate Scholar, Lee Kuan Yew School of Public Policy (LKYSPP). 
the Woodrow Wilson Chair, the first endowed chair in International Relations. Here, Wilson is respected in IR as founder of Wilsonian Idealism, which holds that a state should make its internal political philosophy and goal of its foreign policy. For example, an idealist might believe that ending poverty at home should be coupled with tackling poverty abroad. Wilson's idealism was a precursor to liberal IR theory and liberal ideas of free trade, open agreements, democracy and self-determination was made famous by Wilson's Fourteen Points speech delivered on 8 January 1918. ${ }^{1}$ While Princeton University has a Woodrow Wilson School of Public and International Affairs, in many Universities, the study of PAM and IR were separated in substance. ${ }^{2}$

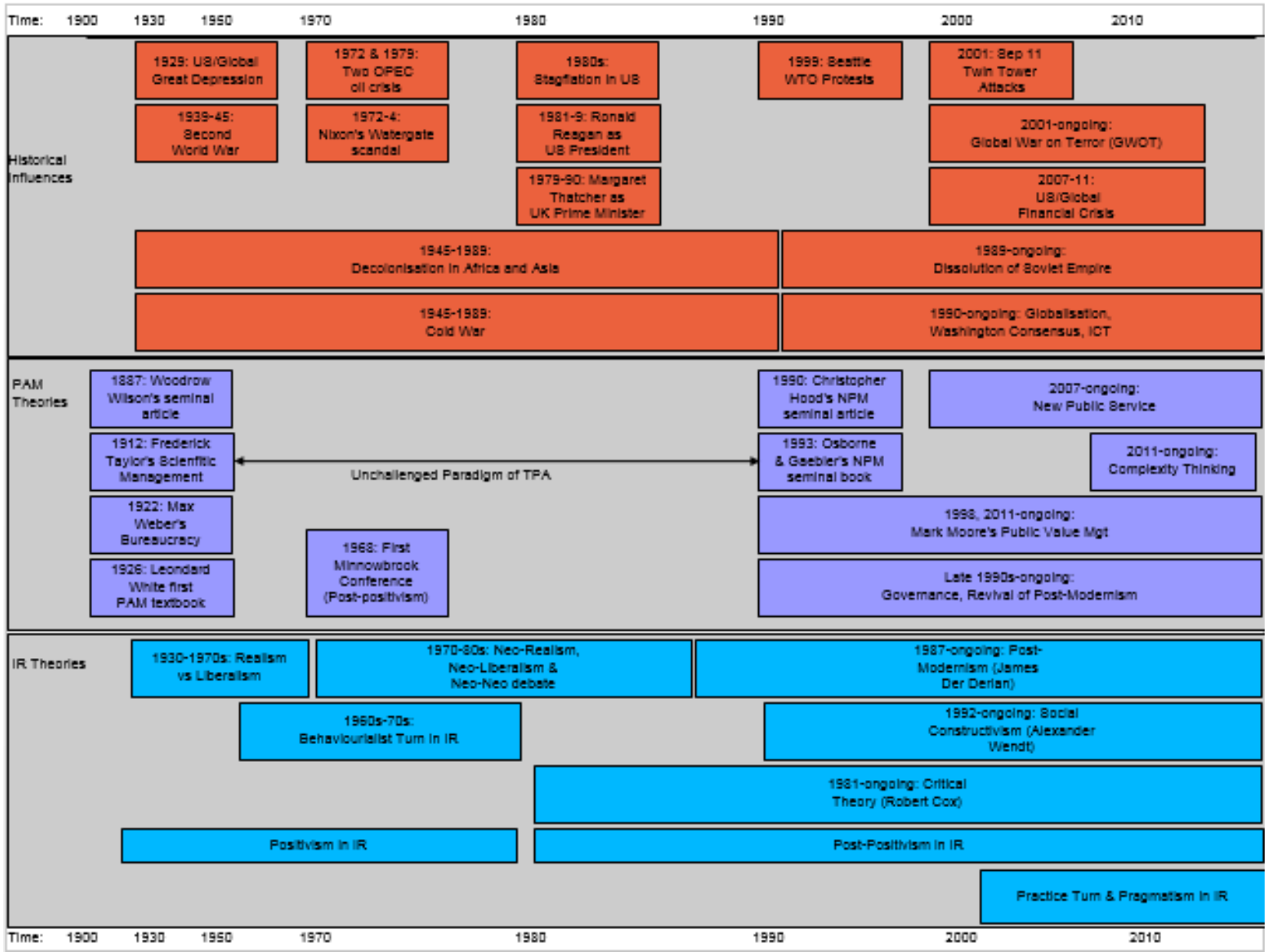

Figure 1. Historical influences on PAM and IR theories.

This is likely due to the "great divide" in IR, the presumption that domestic and international politics are distinct spheres that are defined by distinct organizing principles (Clark, 1999). Hence, there was little appreciation of the increasingly rule-bound nature of decentralized global governance system and interpenetration of rules in the domestic and international realm until the advent of globalization (Barnett \& Sikkink, 2008). Similarly, it was globalization that led to a rethink of the boundaries of PAM beyond the state

\footnotetext{
${ }^{1}$ Retrieved April 20, 2014 from http://wwi.lib.byu.edu/index.php/President_Wilson's_Fourteen_Points

2 The exceptions include: John Hopkins University has a Masters in International Public Policy which is IR in substance. Harvard's Kennedy School of Government recently added an IR concentration to its MPA program. It is questionable if the PAM-IR disciplinary separation has been lifted.
} 
(Farazmand, 1999; Dunleavy, 1994; Klinger, 2004; Dator, Pratt, \& Seo, 2006). New Public Management (NPM) was arguably internationalized in two ways: First, in theory, the internationalisation of NPM can be argued as the result of post Cold War dominance of US-led neo-liberal model (Washington Consensus which is pro-market and anti-state) (Gray, 1998; Minogue, 2001) and policy learning/transfer by bandwagoning countries supported by Information Communication Technology (ICT) and globalization. Second, in practice, NPM was institutionally forced upon non European-Atlantic Countries through World Bank, International Monetary Fund, to some extent UN Development Programme (UNDP), and bilateral donors which require recipient countries to adopt NPM reforms in order to receive aid (Mathiasen, 2005).

However, the attempt of looking at the domestic aspects of IR and international aspects of PAM stopped short of a deep inter-disciplinary discourse. Apart from labeling its international/global version of PAM and vice versa, the scope and objectives of this inter-discipline has been under-theorized. IR can be conceptually defined as how international affairs work while PAM as how (domestic) public affairs work. As such, both can be seen as applied social and policy sciences aimed at tackling public problems at different levels (international, regional and national/domestic). There are at least two complementary ways to build this inter-disciplinary discourse: (1) what can IR offer PAM; (2) what can PAM offer IR, before a research synthesis (Cooper, 2010) effort to consolidate the similarities, differences and interesting aspects in order to lay a coherent foundation of PAM-IR inter-discipline. For reasons of scope and space, this essay attempts to explore the latter research question. PAM will be broadly defined as a discipline that includes sub-fields of PAM theory, Public Policy (PP) Process, Economics, and Political-Economy of Public Policy, amongst others. In each PAM sub-field, similarities, differences, possible overlaps with and potential intellectual borrowing for IR will be discussed.

\section{Historical Influences on PAM and IR Theories}

\section{Orthodoxy: State for Market Failure}

One needs to view the evolution of PAM and IR theories in terms of its historical context. At risk of over-generalizing, some international and national events are highlighted to demonstrate the impact of real events on theorization of both disciplines. Modern PAM theory formally started, as an academic discipline, in the last century with Woodrow Wilson's seminal article in 1887 followed by Leonard D. White's arguably first PAM textbook in 1926. Since then, Traditional Public Administration (TPA), with its application of Taylor's Scientific Management principles and Weber's Bureaucracy (Taylor, 1912; Weber, 1922), was regarded as the paradigm. To a large extent, revolution was a crucial influence in transforming monarchial systems of government into modern bureaucracies (Minogue, 2001, p. 4). Two world wars and interwar depression (1929) meant that central coordination of resources was important in the management of ravaged economics; this led to the post-1945 Keynesian Consensus and "welfare state". Concomitantly, this period also witnessed the decolonization and the rise of "developmental" states (Minogue, 2001). Together with the Cold War which entailed strong government planning of military and strategic affairs, these required primacy of the state over other sources of power such as markets or civil society. In IR, the equivalent of TPA is perhaps Realism (focused on State Actor's propensity towards power politics) (Morgenthau, 1985, pp. 1-51; Carr, 1946; Thucydides, 1910, Book 1, paras 1-23, 66-88, 118-24, 140-46; Book 4, paras 37-51; Book V, Melian dialogue; Book 6, paras. 84-116) and its Neo-Realism variant (Waltz, 1959; 1979) (focused on Structural Anarchy), which focused on the primacy of the state in IR. 


\section{New Orthodoxy—Markets for State Failure}

However, this TPA paradigm began to be increasingly challenged by real events in 1970s. Economically, the 1970s OPEC oil crisis affected US which was heavily dependent on oil; coupled with the US stagflation (economic stagnation with inflation) in 1980s, these indirectly highlighted the weaknesses of Keynesian economics and ushered in its Monetarist competitor spearheaded by Milton Friedman. Politically, the Watergate scandal involving President Nixon increasingly led the US populace to lose confidence in its elected representatives. Given these exogenous events in the 1970s, then came in US President Ronald Reagan and UK Prime Minister Margaret Thatcher, in the 1980s, who brought in neo-liberal ideas to address "government-failure" (Minogue, 2001, p. 5) by reasserting the primacy of the elected politician over the bureaucrat as well as trimming the "fat" bureaucracy using private sector management principles; ${ }^{3}$ this NPM was later codified as an intellectual movement in early 1990s, best represented by Osborne and Gaebler's Reinventing Government (1993). In IR, the equivalent of NPM is perhaps Liberalism (c.f. Wilsonian Idealism; focused on State Actor's propensity towards morality) (Axelrod, 1984, pp. 3-105, 145-91; Doyle, 1986) and its Neo-Liberalism variant (focused on Structural Interdependence) (Keohane, 1986), which focused on the primacy of market and how they influenced State actors to move beyond power politics. The difference with PAM is that, in PAM, it was TPA then NPM in sequential transition of paradigms. In IR, both Realism and Liberalism and their neo-neo variants were in competing camps at the same time periods; it transited from an actor-focused Realism-Liberalism debate to a structure-focused Neo-Neo debate (Powell, 1994).

Both disciplinary paradigms can also be seen in the context of agency-structure debate and positivist paradigm. In Realism vs Liberalism, the debate was on agency and within a positivist paradigm whereby agency will, by nature, act in a certain manner (period). Agency in the PAM context would probably refer to TPA's state vs NPM's market. Neo-Realism and Neo-Liberalism focused on structures in international relations that drive agents to behave in a certain manner (period); Structures in the PAM context would probably refer to role in institutions in PP literature and how government structures (classical institutionalism) determine policy outcomes (Weaver \& Rockman, 1993). There was even an agency-structure debate arguing whether structure, by itself, drives agents to behave in certain manner or agents have self-volition to behave as they wish (Dessler, 1989; Wendt, 1987). This structure-agency debate can also be observed within PP with the policy dynamics frameworks such as Ostrom's Institutional Analysis and Development (IAD) (Ostrom, Schroeder, \& Wynne, 1993; Ostrom, 1990) and Sabatier's Advocacy Coalition Framework (ACF) (Sabatier, 1988).

\section{Globalization: Post-Positivism}

Globally, the end of Cold War ushered the dominance of US hegemony, democratization, coupled with increased globalization enabled by the popularization of ICT. While these global exogenous forces are hard to measure, a few milestone events can act as proxy measures of its effects and they include: (1) 50,000-100,000 anti-trade/pro-democracy protesters from all over the world congregating in Seattle against the WTO meeting there in Nov $1999 ;^{4}$ this signifies the power of civil society, people and networks across borders; (2) 11 September $2001 \mathrm{Al}$ Qaeda attacks on World Trade Centre in New York signifies the power of transnational terrorism enabled by globalisation (of security) and ICT. Collectively, these events brought an awareness that

\footnotetext{
${ }^{3}$ NPM had two constituent theoretical paradigms. The former emphasis represented Public Choice Theory and the latter represented Managerialism (Aucoin, 1990).

${ }^{4}$ Retrieved November 1, 2013 from http://www.globalissues.org/article/46/wto-protests-in-seattle-1999
} 
civil society (enabled by citizens and networks) is a key stakeholder to be reckoned with.

A couple of "post-positivist" PAM theories took the fore-stage during this period. First, Public Value Management (PVM) (Moore, 1998; Bennington \& Moore, 2011) reasserted the primacy of citizens and called for "inclusive management" to maximize public participation, "active user involvement in service design and delivery" to the extent of "co-production" (Bennington \& Moore, 2011, p. 25). The fact that PVM was co-developed between theorists and practitioners is evidence of the practitioners' realization of the need to engage civil society and citizens. Second, Governance (New Public Governance) (Kjaer, 2004; Ingraham \& Lynn, 2004), with its roots in organizational sociology and network theory (Osborne, 2006), had to accept the increasingly fragmented and uncertain nature of PAM (Haveri, 2006) and include the following aspects of participative (with public consultation and negotiation) (Peters, 1996; Frederickson, 2005) and flexible government (Frederickson, 2005, p. 288) through E-Government (Snellen, 2005) and Virtual Organizations (Margetts, 2005); focus on non-state institutions (non-profit and for-profit contractors, non-governmental organizations, inter-governmental organizations) (Frederickson, 2005, p. 290) and networks (Rhodes, 2000) to "do its work" (Kettl, 1993, p. 21); and primacy of citizens as "equal partners" to Governments in "Collaborative management" (Vigoda, 2002). The fact that NPM pioneer countries of US, UK, Australia and New Zealand adopted governance reforms (Peters, 1996; Frederickson, 2005, p. 287) is evidence of the common global circumstances that rendered NPM useless and engendered a rethinking of a PAM theory that can address reality. Third, New Public Service's (NPS) (Denhardt \& Denhardt, 2007), which focused on serving citizens (not customers), valuing citizenship (over entrepreneurship), thinking strategically and acting democratically and valuing people (not just productivity) (Denhardt \& Denhardt, 2007), is essentially reasserting the primacy of citizens as part of the democratisation process. Fourth, Postmodernism (Frederickson \& Smith, 2003, pp. 127-159) (technically widened to include the Minnowbrook Conference series ${ }^{5}$ which championed post-positivism (Lejano, 2013) since late 1960s albeit the difference between anti-foundationalist Postmodernism and foundationalist post-positivism is noted) can be considered as the epistemological twin of PVM/Governance/NPS. PVM's focus on multiplicity (actors, goals, objectives, preferences, accountability, alternatives) and relationships (O'Flynn, 2007) reflects post-positivism; NPS is a self-declared Postmodern project (Denhardt \& Denhardt, 2007, pp. 39-42). Postmodernism advocates for democratization, citizen empowerment and civil society, all of which are key terms afore-covered by governance and NPS.

In IR, positivism was greatly challenged by the post-positivists since the end of Cold War (Smith, Booth, \& Zalewski, 1996). There were various camps: First, Critical Theorists argued that "theory is always for someone and for some purpose" and that civil society is necessary to counter the Gramscian hegemony of the state (Cox, 1981, p. 128), hence respectively refuting the value-free claim of positivism and unitary and unchallenged influence of the state. This emphasis on civil society (power to citizens) enabled by networks, democratization and globalization parallels that of PVM/Governance/NPS in PAM and can be argued as an outcome of the intellectual influence of Jurgen Habermas's Frankfurt School of Critical Theory (Cox, 1983) from Sociology (Gottlieb, 1981). Second, Social Constructivists (Wendt, 1992; Wendt, 1999; Adler, 1997; Ruggie, 1998) argued that "anarchy is what states made of it" and that international politics is socially

\footnotetext{
${ }^{5}$ Syracuse University Minnowbrook Conference since late 1960s have actively challenged the orthodoxy with its core ideas in postmodern public administration such as public administration cannot be neutral; technology is dehumanizing; public administration must be built on post-behaviorial and post-positivist logic of more democratic, more adaptable, more responsible to changing social, economic and political circumstances (Frederickson \& Smith, 2003, p. 128; Anonymous, 2011).
} 
constructed by ideas (Goldstein \& Keohane, 1993), interests (Finnemore, 1996), culture (Katzenstein, 1996) and norms (Barkin \& Cronin, 1994), rather than "out there to be discovered" in the (positivist) natural sciences. Social Constructivism can be seen as a response to agency-structure debate; instead of arguing primacy of either agency or structure, social constructivism focuses on interactions (Giddens, 1984; Bathlet \& Gluckler, 2011, pp. 21-44) ${ }^{6}$ that gel agencies and structures together such as ideas, culture and norms. This has much parallel in PP literature on role of institutions (norms and cultures in sociological neo-institutionalists) (Hall \& Taylor, 1996), interests and ideas (Braun, 1999). In PAM, the roles of ideas, culture and norms can be inferred from PVM where citizens will search for what is good (public value) for wider society (Bennington \& Moore, 2011, p. 24). This reflects the larger intellectual influence of Lev Vygotsky's (1978) Social Constructivism/Constructionism from Sociology and Psychology. Third, Postmodernists (Der Derian, 1987; Walker, 1992; George, 1994; Edkins, 1999) argued that meaning is negotiated through discourses and is relative to context. As aforementioned, PAM has its own strand of postmodernism and hence reflecting the intellectual influence of sociolinguists and philosophers as Foucault and Derrida on both PAM and IR.

\section{Globalisation: Governance}

It is noteworthy that both PAM and IR theories converged on the topic of Governance albeit with varying origins and focus which is articulated in Chhotray and Stoker's Cross-Disciplinary Approach on Governance Theory and Practice (Chhotray \& Stoker, 2009, pp. 16-52; pp. 76-96). In PAM, there are five propositions of Governance: (1) refers to set of institutions and actors drawn from but also beyond government; (2) identifies blurring of boundaries and responsibilities for tackling social and economic issues; (3) identifies power dependence involved in relationships between institutions involved in collective action; (4) about autonomous self-governing network of actors; and (5) government to steer and guide (Stoker, 1998, p. 18). The emphasis is on self-organising and inter-organisational networks, citizens and civil society where the role of community, voluntary and private sectors in delivering public services is key (Chhotray \& Stoker, 2009, p. 19). The potential overlap with IR is in the governance turn in European Union (EU) studies, which focused on "multi-level, non-hierarchical, deliberative and apolitical governance, via a web of public/private networks and quasi-autonomous executive agencies" (Chhotray \& Stoker, 2009, p. 10). Indeed, there were attempts to ensure the "proper use of governance" in IR, as the initial definition in James Rosenau's Governance without Government was tautological ${ }^{7}$ and vague as it "included everything, elucidated nothing and in no way facilitated research". ${ }^{8}$ In his rebuttal of Rosenau, Finkelstein suggested that "Global Governance is doing internationally what governments do at home" (Finkelstein, 1995). Therein, lies the potential contribution of PAM's Governance to IR's Global Governance. At risk of over generalisation, in IR, while there is consensus on globalization as the context, the Governance discourse suffers from the hegemony of neoliberalism and its normative emphasis on democratization (Chhotray \& Stoker, 2009, pp. 76, 92, 94). Therefore, PAM's governance can help IR's governance break away from its theoretical baggage of neo-liberalism and explore

\footnotetext{
${ }_{7}^{6}$ In Sociology, this approach is called structuration.

7 In Governance without Government, Rosenau noted that regimes exist only in quite well-defined areas, whereas governance is inseparable from global order and is not confined to a single sphere of endeavor. However, Smouts noted that there can be no governance without global order and there can be no global order without governance. Hence, the reasoning is trapped in tautology (Smouts, 1998, pp. 81-82).

${ }^{8}$ Later in Global Governance, Rosenau defined global governance to include systems of rule at all levels of human activity-from family to international organization - in which the pursuit of goals through the exercise of control has transnational repercussions and even comprises vast number of rule systems that have been caught up in the proliferating networks of an ever more interdependent world (Smouts, 1998, p. 82).
} 
global governance from a bottom-up perspective, e.g. how to increase public participation in cosmopolitan governance (Held, 1995), operationalize E-Government (Snellen, 2005) and Virtual Organizations (Margetts, 2005) at the international level. The growing use of institutional analysis (akin to the New Institutional Economics (NIE) used in Political Economy of Public Policy) in the study of the multi-level governance in the EU (Jupille \& Caporaso, 1999) is a step in the right direction and this can be proliferated to the study of International Organizations.

\section{“Global Wicked Problems" of Chaos, Uncertainty and Complexity: Complexity Thinking}

The next watershed event is probably the US/global financial crisis in 2007-2011, ${ }^{9}$ which highlighted the complex and uncertain nature of (economic reality) and that these wicked problems are hard to resolve without making trade-offs and engaging all stakeholders. A political corollary is probably the Global War on Terror (GWOT); amidst the decade long GWOT in Iraq and Afghanistan, there was a realisation, during the Obama administration, ${ }^{10}$ that toppling the Taleban and Saddam regime (wicked problem) was not sufficient to usher peace in the region and that the complex (politico-strategic) reality required engagement of international and regional stakeholders. These events probably provided the context to CT/NS (Bourgon, 2011b; Rhodes, Murphy, Muir, \& Murray, 2011; Morcol, 2012) since 2011. CT/NS saw public administration as a dynamic system with the capacity to adapt to changing circumstances and to co-evolve with society: government transforms society and is transformed by it (Bourgon, 2008; Bourgon, 2010). It argues that "public results are a combination of public policy results and civic results" and public servants, as stewards, are to "mediate and leverage on collective capacity (of public, private and civic spheres) for better results" (Bourgon, 2011a). Its emphases on dynamism (non-linearity), adaptability, co-evolution, synergistic co-production with public, private and civic spheres are evidence that blind faith on NPM's linearity, markets, steering, productivity and results are insufficient to deal with wicked problems such as global financial crisis. Philosophically, CT is beyond dualism (e.g. TPA's pro-state vs NPM's pro-market) and embraces the "Power of \&" (Simon \& Tay, 2010, p. 13) in generating consensus, and co-producing with multiple stakeholders across systems and boundaries in "one-ness"; this can be seen in Obama's abandonment of the Bush dualist rhetoric of "you are either with us or against us in the fight against terror"11 and instead embarked on a "all countries are close allies" 12 rhetoric. This admission of complexity is also found in Moore (2011) revised version of PVM where he acknowledged the changing context as "complex adaptive systems" (CAS) and the need to "make sense of this complex new pattern of polycentric networked governance" (Bennington \& Moore, 2011, p. 15) (link to networked Governance). As such, Moore (2011) reformulated PVM to guide "networked community governance" (NCG) and focus on relationships between state, civil society and citizens (Bennington \& Moore, 2011, p. 35).

The latest addition in IR is a "Practice turn" (de Felice \& Obino, 2012) with emphasis on Pragmatism in IR. The discourse of Pragmatism in IR is still in its infancy and comprises mainly theoretical exposition, rather than empirical studies of Pragmatism at work in IR or specific country's foreign policy. The earlier works of Millennium Journal Volume 31 in 2002 explored the theoretical possibilities of Pragmatism as an alternative

\footnotetext{
${ }^{9}$ Retrieved November 1, 2013, from http://www.theguardian.com/business/2011/aug/07/global-financial-crisis-key-stages

${ }^{10}$ This is evident in 2010 National Security Strategy which steered away from George W. Bush's unilateral military might and emphasized on engaging US's allies and partners in GWOT. Retrieved November 1, 2013, from http://www.washingtonpost.com/wp-dyn/content/article/2010/05/27/AR2010052701044.html

11 Retrieved November 2, 2013 from http://edition.cnn.com/2001/US/11/06/gen.attack.on.terror/

12 Retrieved November 1, 2013, from http://blogs.telegraph.co.uk/news/nilegardiner/100190755/obama-administrationdeclares-we-have-no-greater-ally-than-france-what-about-britain-canada-and-israel/
} 
paradigm. Seven years later, Bauer and Brighi (2009), followed up with an edited volume, Pragmatism in IR; it represented ironically a European effort to deeply explore the (American-originated) Pragmatic approach to IR in an attempt to "transcend the variety of well-worn debates that run the risk of paralyzing the field" (Little, 2009, pp. xii-xiii), with a focus on specific historical practices. Ralston's edited volume, Philosophical Pragmatism and International Relations (Ralston, 2013) represents the latest effort to describe and explore the nexus of Philosophical Pragmatism as an alternative paradigm in IR. However, even in this latest work, discussions were at the "what" level using theoretical normative arguments, rather than at the "how and why" level supported by empirical research and case studies, e.g., Weber expounded on how Pragmatism can improve IR theory through (1) empirical insight that concrete problems, not grand theories, should be at the fore of their explanatory models; (2) "stoic optimism" or the belief that a prudent and productive path towards solving global problems lies somewhere between the extreme theoretical perspective (e.g. Realism and Liberalism); (3) the notion of "collaborative culture" or that attention the social cultural context, not simply isolated agents and their motivations, promises theorists and practitioners a more holistic understanding of the international situation (Weber, 2013); these normative statements are more the potential research benefits of a larger research program, than the research findings of Pragmatism in IR per se. Goldman suggested Pragmatism could "reframe the study of IR within a context-sensitive and post-theoretical pragmatist perspective", beyond the current Realist vs Liberalist; Positivist vs Post-Positivist traditions, and "even end grand theory" altogether (Goldman, 2013). The cases of Pragmatism in IR often referred to the US, from the broad-based "American Diplomacy and the Pragmatic Tradition" (Crabb, 1989) to the recent Obama's Pragmatism (Butler, 2013). IR would require thicker descriptions of how and why Pragmatism works in IR, supported by empirical data from single and multiple case studies.

However, IR could also benefit from a CT in IR to complement the Pragmatism's contextual problem-solving approach and attempt to reduce the theory-praxis gap. CT in IR would instil an epistemology that recognises the dynamism, chaos, non-linearity and adaptability that mirrors the ontological reality that International Organizations operate in. Hence, PAM's CT and governance will enhance IR's ability to theorize how International Organizations work in practice. In operational terms, this means strengthening the Global Governance discourse in explicating how normatively public, private and people sectors at the global level could work together to co-produce desired global/international public goods. If the latter is the research problem, the inclusion of CT augurs well with Pragmatism's problem-solving approach (solve problems of global/international public goods to bridge its positive reality with the desired normative vision).

\section{Public Policy Process for International Public Policy}

In the Handbook of Global International Policy, Nagel (2000) defined International Policy as: (1) international competitiveness; (2) tariff reduction; (3) making provisions for workers displaced as a result of tariff reductions; (4) immigration policy; (5) international refugees; (6) volunteerism in technical assistance; (7) foreign factories in the US; (8) US factories going abroad; (9) dollar exchange rates; (10) international economic communities; and (11) exporting democracy in making foreign policy decisions (p. 1). Apart from failing to distinguish global and international policy, this definition of International Policy is rudimentary on several accounts. First, (11) explicates a bias towards US lenses of "exporting democracy". Second, it is overly focused on international economic policy as seen in (1)-(3); (7)-(10) with slight digression on to international social policy in (4)-(5). A reference to other Handbooks highlighted the importance of other International 
Policies: Economics (Martin, 2006) (Finance and Trade) (Cohen, 2002; Milner, 2002), Social (Development, Environment, Health, Human Rights) (Maxfield, 2002; Mitchell, 2002; Schmitz \& Sikkink, 2002), Legal (International Law and Judiciary) (Raustiala \& Slaughter, 2002), Political and Security (Higgott, 2006; Duffield, 2006) (Nuclear Non-Proliferation, Security Cooperation, Peace-making and Conflict Resolution) (Carlsnaes, 2002; Muller, 2002; Gilady \& Russett, 2002); as well as other transnational actors such as International NGOs (Florini, 2006) and Regional Governmental Organizations (Choi \& Caporaso, 2002) and their policies ${ }^{13}$.

IR has a respectable literature on the substantive "content" issues of IPP focusing on the "what and why" aspects. However, PP can offer perspectives into the procedural (who and how) aspects of "Global Governance" (how it should work by extrapolating successful procedures from the national and regional [EU] levels) and interactions between actors (who and how) that determine the success of IPP beyond agencies' volition and structural constraints. This will push the study of IPP beyond the agency-structure debate to include ideas, interests, culture and norms (c.f. operationalising Social Constructivism in IR).

The five-Step Policy Cycle and three Policy Sub-Systems (Howlett, Perl, \& Ramesh, 2009) of PP will be used as a working framework to explore PP's potential contributions to the IPP process:

(1) Agenda-Setting. Agenda-setting talks about focusing events (Birkland, 1998) where exogenous shocks and significant events allow mobilisation of public opinion and enable non-government actors to set the agenda. The classic Kingdon's Multiple-streams Framework (MSF) (Kingdon, 1995) talks about problems, policies, politics, policy windows, and policy entrepreneurs. Problems streams are the conditions (policy problems) that policy makers and people want to address such as environmental problems, transportation, health care, and so on. Policies streams are all the ideas that compete to receive attention. The politics streams consist of three elements: the national mood, pressure group campaign, and administrative or legislative turnover. Policy windows streams are defined as fleeting opportunities for advocates of proposals to push their pet solutions, or to push attention to their social problems. Policy entrepreneurs are individuals or corporate actors who attempt to couple their three streams (problems, policies and politics) and seize the opportunity to initiate action when the policy window opens. Problems happen when policy entrepreneurs use the wrong window to pursue their goals. Punctuated-Equilibrium Framework (PEF) (True, Jones, \& Baumgartner, 1999) talks about the stability and punctuated change in policymaking due to policy incrementalism. It will be useful to examine: (1) what constitutes focusing events; (2) how MSF works for different transnational non-state actors to set agenda; and (3) how PEF would work at the international level.

(2) Formulation. Formulation talks about Policy Design and Transfer (Schneider, 2013), Policy Analytical Capacity and Evidence-Based Policy-Making (EBPM) (Howlett, 2009), and the role of epistemic communities (Dunlop, 2013). Evans and Davies wrote a useful piece on Policy Transfer using a multi-level perspective and concluded that policy transfers research is weakest at the global, international and transnational level (Evans \& Davies, 1995, p. 365). If the International Civil Service in United Nations and other International Organizations were to embark on EBPM, then it would need to enhance its policy analytical capacity and systematically co-opt inputs from epistemic communities and other international policy and issues networks.

\footnotetext{
${ }^{13}$ Note: Global Public Policy suggests that there is a coherent Global Governance system where state actors and transnational non-state actors (private and people sectors) and citizens act in tandem towards global public goals. However, in reality, this is not the case. While there is some 'hallowing out of the state', the primacy of the state still remains the potent force in IR, coupled with inclusion of new and more diverse transnational non-state actors which can interfere with International Public Policy (IPP); decision power remains with the state actors. Hence, to be clinical, IPP is a more accurate representation of current reality and will be used in this essay.
} 


\section{VALUE OF PUBLIC ADMINISTRATION MANAGEMENT TO INTERNATIONAL RELATIONS}

(3) Decision-Making. Decision-making talks about decision-makers' perceived Rationality (Andrews, 2007) and Bounded Rationality (Jones \& Thomas, 2013). Incrementalism talks about why policy changes tend to be incremental as decision-makers muddle through using trial and error, or because of political gridlock or simply bureaucratic incompetence (Hayes, 2013; Lindblom, 1959); it is useful to compare domestic and IPP incrementalism. The Garbage-Can Model (Cohen, March, \& Olsen, 1972) depicts organizational anarchy whereby there are many solutions, devised on its own and distinct from problems that require attention, that are discarded due to lack of befitting problems. The other two variables are choice opportunities for decision and fluid participation. Hence, instead of an orderly decision-making process from problem to solution, Garbage-Can Model yields decisions that are outcomes of several relatively independent stream of events within the organization. It will be useful to contrast this with IPP decision-making - is it affected by organizational anarchy too? Multi-Actor-Multi-Round (Howlett, 2007) talks about democratic decision-making and negotiation between many actors and through many rounds; this is directly relevant to multilateral negotiations.

(4) Implementation. Implementation talks about policy implementation (top-down and bottom up approaches) (O’Toole, 2000), use of networks (Agranoff \& McGuire, 2013) and regulations (Hawkins \& Thomas, 1989). It is useful to consider the IPP equivalent: International bureaucrats and its street-level bureaucrats (Sabatier, 1986) who implement policies on the ground. It is also useful to consider the international equivalent of PAM's politics vs administration dichotomy: International Political Leadership vs International Bureaucrats. Networks are an enabler to maximise policy reach and effectiveness. Beyond setting international regulations and governance standards, International Organisations also do provide and produce certain international public goods such as health and heritage.

(5) Evaluation. Evaluation talks about the politics of evaluation (Palumbo, 1987), policy successes and failures (McConnell, 2013), policy learning and feedback (Bennett \& Howlett, 1992), public participation (Hendriks, 2013) and policy (non)-termination (Geva-May, 2001). It will be interesting to note the different nuances of politics in the evaluation of IPPs; will policy failures be covered up and only successes sung? How is policy learning and feedback done for IPP, or it is even done since some IPPs are tragedy of the commons and actors will often free-ride over such collective action problems. How much leverage does public participation through internet means and the international media have over policy evaluation, and will bad policies be terminated? (c.f. domestic policy failures tend not to be terminated as that is oft-considered political suicide).

(6) Actors. PP's multiple actors drew inspiration from IR's epistemic communities (Haas, 1992). It further included Policy (Marsh \& Smith, 2000; Raab \& Kenis, 2007; Peters, 1988) and Issues Networks (Heclo, 1978). The classic Advocacy Coalition Framework (Sabatier, 1988) talks about how different policy advocates gets aggregated into advocacy groups to share resources and develop complementary strategies to push for solutions against wicked problems (substantial goal conflicts, technical disputes and multiple actors from several levels of government) in a pluralist decision-making environment. There is much scope to extrapolate such concepts to the international level especially for multilateral negotiations and IPP-making

(7) Institutions. Institutions talk about policy regimes (Weaver \& Rockman, 1993), durability and change (Clemens \& Cook, 1999), policy trajectories and path dependency (Kay, 2013). Incidentally, PP borrowed the concept of regimes from Krasner's International Regimes (Krasner, 1983). In IR, regimes have evolved to International Institutions and Global Governance (rather macro-level aspects). In PAM, it borrowed concepts 
from sociology, economics and decision sciences, amongst others to further explore how institutions work at the micro-level and this is where PAM can be useful to IR (see Political Economy below).

(8) Ideas. Goldstein \& Keohane's seminal Role of Beliefs and Ideas in FP (Goldstein \& Keohane, 1993) had a pivotal influence in PP's role of ideas. Enduring ideas, rather than diverse/ad hoc interests, lead to policy paradigms that in turn drive policy actions; ideas may be iterated in discourses (discursive institutionalism) (Schmidt, 2008). Here, the enduring ideas may be Washington Consensus and the non-Consensus of the Post-Washington Consensus ${ }^{14}$, amongst others, and it is useful to draw linkages of how ideas from elites are proliferated and institutionalized and further permeated to influence other actors. One such idea is the primacy of the free-market economies (neoliberal).

\section{Economics: International Public Finance}

Economics of Public Policy essentially talks about property rights, economic efficiency, externalities and the need for public provision of public goods, regulation and redistribution, amongst others. Besides regulations, Governments influence citizen behavior through taxation and expenditures (Holcombe, 2005). The latter two is very much under the ambit of Public Finance. Here, it is useful to note the critical lack of a system of international public finance (IPF) to examine international market failures, distributional equity of income and wealth across nation-states, macroeconomic stabilization and coordination of firms, individuals and nation-states in the world economy, international taxation, global commons (common property and public goods) (Mendez, 1992, pp. 1-22). That Mendez wrote a book length on this in 1992 was significant; that not many books on this topic have been written since and nothing much seen in practice is more significant. In 1992, Mendez noted the positive reality: "present international public financing is mainly based on voluntary contributions inability or refusal for public finance theorists to look beyond the nation-state stem from the absence of a full-fledged world government with the power to tax and enforce its tax laws" (Mendez, 1992, pp. 35-37). Mendez (1992) registered his normative vision:

Government and rule of law are a matter of degree ... United Nations has no coercive powers of enforcement, but compulsive factors exist in the form of penalties (loss of right to participate in General Assembly), loss of self-respect, and weight of public opinion. (p. 37)

Mendez's public finance perspective revealed the limits of the Bretton Woods system [of International Monetary Fund (IMF), now World Bank (WB), and now World Trade Organization (WTO)] in being historically and hitherto dominated by free-market industrial powers and operated based on weighted voting which favored the "have" nations. This was at the expense of developing countries, who congregated at more universal-membership-based United Nations Conference of Trade and Development (UNCTAD), International Finance Corporation (IFC) acting as counter-weights to WTO and WB (Mendez, 1992, pp. 166-71).

Hence, if IPF is to work, it has to be implemented at the UN, where assistance was based on need, and there needs to be proper system of taxation and expenditures to reduce the existing overlaps and inefficient international fund allocations. E.g. UNDP is the largest multilateral assistance program but is restricted to

\footnotetext{
${ }^{14}$ Post-Washington Consensus was used in different ways to express the "consensual" abandonment of Washington Consensus (market fundamentalism and reliance on foreign capital) in non-Western states especially after the financial crises in East Asia and Latin America in 1990s. Surprisingly, post 1990s crises taught these non-western emerging-market and low-income states to reduce exposure on foreign financial markets and regulate their banking which insulated them from the full effects of the global financial crisis. This Post-Washington Consensus is creatively adapted to express instead the (Non)Consensus on what's next for economic thinking after the global financial crisis (Birdsall \& Fukuyama, 2011; Stigliz, 2014).
} 
technical assistance and pre-investment activities, whilst leaving the larger scale capital investment projects to the WB, which is essentially Western funding for Western-oriented nation-states (low distributional equity) (Mendez, 1992, p. 177). The identified seeds of "international government" for which expenditures from international taxation should go to are: (1) Peacekeeping-Security Council, General Assembly, Secretariat; (2) Administration of Justice-International Court of Justice, Peacekeeping organs; (3) Legislation-Security Council, General Assembly, Secretariat and other UN agencies; (4) Technical Ministries-UN specialized agencies; (5) Development and finance-WB, UNDP, Regional Development Banks; (6) Central Bank-IMF; and (7) Fair Trade Practices-WTO (Mendez, 1992, pp. 206-207).

But it is a great irony that the "most universal organization (UN) also has the least resources and least authority on financial matters, whilst the most resourceful and powerful organizations are the least universal and operate along oligarchic rather than democratic lines" (Mendez, 1992, p. 207). Therein lies the importance of Political-Economic aspects of Public Policy, which we will now turn to.

\section{Political Economy: New Institution Economics}

Finally, New Institutional Economics (NIE) looks at the political and economic factors holistically at play on a particular policy issue. Philosophically, NIE can be seen as focusing on the relational factors of interactions, rather than pure agency or structures as determinants of outcomes (akin to operationalizing IR's Social Constructivism, beyond agency-structure debate, and in a problem-solving context, c.f. IR's Pragmatism). The Institutional Analysis Design (IAD) framework, representative of NIE, is a case in point. With reference to Figure 2, the IAD notes the structural (in external variables and broader social-ecological system as context) and agential factors (actors), but focuses on interactions (in action situations and interactions) in order to produce outcomes (Aligica \& Boettke, 2009; McGinnis, 2011). Hence, logically, similar structural and agential factors might still lead to different outcomes due to variations in interactions.

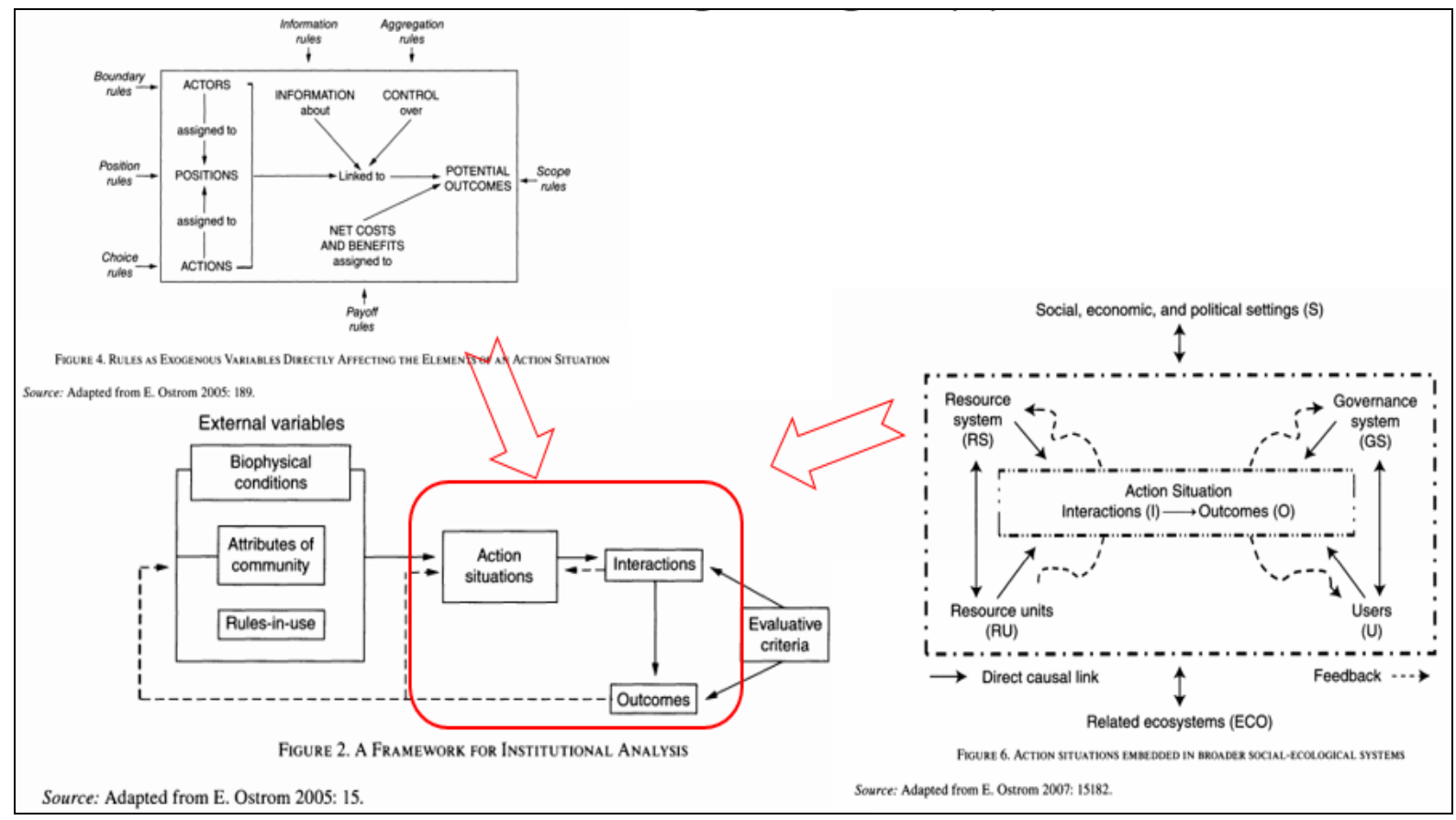

Figure 2. Institutional analysis design framework. 
Other sub-topics of NIE are also relevant to IR and IPP:

(1) Rational and Public Choice Theory. While Public Choice Theorists (Stigler, 1962; Buchanan \& Tullock, 1962), applying Rational Choice Theory (Sen, 1977) in neo-classical economics into Political Science, noted the self-maximizing bureaucrats who act to maximize self-interests over public interests, there is scope to expand the hypothesis to examine, with empirical data, the extent that international bureaucrats and international political appointments (e.g. UN Secretary-General, President of WB) would maximize self-interest.

(2) Property Rights. Domestic rule of law secures property rights and enables economic growth and social trust (De Soto, 2001; Anderson \& McChesney, 2003). Will the same global outcomes be achieved if international property rights were secured by international rule of law (and enforced by international government/global governance)? On this note, the international law debate on transiting Public International Law into International Public Law as a legal framework for the exercise of International Public Authority to support Global Governance is a useful area for further research (von Bogdandy, Dann, \& Goldmann, 2008; Kadelbach, 2009; Vezke, 2010).

(3) Transaction Costs. Transaction cost talks about hidden costs of low social trust, legal procedures, contract enforcement that exist in a low trust environment. NIE don Ronald Coase wrote that the firm (hierarchy) was created to reduce such transaction costs (Coase, 2007; Williamson, 2013). An international political variant was provided by Heritier who, in articulating European's mode of governance, introduced the political transaction cost theory, which uses delegation to reduce political transaction cost arising from long discussions and negotiations among political actors (Epstein \& O’Halloran, 1999; Héritier, 2003, p. 107). A further exploration of economic and social transaction costs at the international levels would deepen the discourse.

(3) Mechanism Design. With reference to IAD, mechanism design (Maskin, 2010) talks about the desired outcomes and work backwards to ascertain the mechanisms (structural, agential, interactionist variables), from "best practices", required to ensure that inputs lead to desired policy outcomes. Here, accumulated quantitative Meta-Analysis and/or qualitative Research Synthesis (Cooper, 2010) of "best practices" can strengthen the propensity for international bureaucrats to deliver desired IPP outcomes.

(4) Governance Systems. In a Polycentric system (McGinnis, 1999) (c.f monocentric system where Government is in charge of both provision (finance) and production (delivery) of public goods), public, people and private sectors can be in charge of provision and production of public goods in a dynamic fashion. It is useful to consider a Global Polycentric system as the epitome of Global Governance: Here, Doctors without Borders (INGO) is privately funded and produced by people sector. Transnational Public-Private Partnerships demonstrates the co-provision and co-production of public goods by public and private sectors, hence improving the effectiveness and legitimacy of Global Governance (Schaferhoff, Campe, \& Kaan, 2009, p. 452).

\section{Conclusion}

At risk of over-generalization, the current knowledge enterprise is overly specialized due to professionalization of academia along disciplinary stovepipes. As a result, it is common for social scientists to be generally unaware of knowledge discovery of its sister disciplines. It is ironic that new knowledge is often discovered at the inter-disciplinary boundaries. E.g. International Political Economy (IPE), a new sub-field in IR, was established in the 1980s to examine the intersections between IR and Political-Economy (classical economics). Now, it is timely to consider the nexus between PAM and IR. 
This essay dissected PAM's sub-fields and elicited value for IR's consideration. PAM theory offers Complexity Thinking. For example, Rhodes, Murphy, Muir, and Murray (2011), wrote about Complexity Thinking (in the form of Complex Adaptive Systems) and how it exhibits dynamic characteristics of self-organization, adaptation, path-dependency, emergence, and bifurcation ${ }^{15}$ in Public Management. Morcol dissected Complexity Thinking from conceptual, epistemological and methodological perspectives. It views public policy and organizations as a complex (living) system like a biological and human systems that are contextually (non-reducible to simple laws) and socially constructed (non-deterministic) due to complex interaction with system actors; adaptive and resilient (not static) as a system where change is dynamically and endogenous driven (internal cause) in close interaction with external stimuli/environment (exogenous); and changes with time (non-linear) (Morcol, 2012, pp. 1-44, 143-162, 262-275; Morçöl, 2002; Dennard, Richardson, \& Morçöl, 2008, pp. 197-214).

PP offers a "process" perspective to look at IPP-making through five-step policy cycles and three policy sub-systems. Economics offers an IFP lens to relook into the fiscal aspects (taxation and expenditure) of UN and Global Governance. NIE offers an institutional viewpoint and philosophical "interactionist" approach to understand the policy dynamics behind IPP. These intellectual borrowings from PAM will strengthen IR's repertoire particularly in the IPP realm. Henceforth, IPP, as a hitherto incoherent and uncoordinated sub-field of IR, can confidently address policy issues from both the macro-micro, and agency-structure-interactions perspectives, with empirical data from both PAM and IR to enhance external validity of its theories across national, regional and international levels. Whilst enforceability of IPP will always be a moot point due to absence of world government, the mantra of today is about getting things done through persuasion, rather than coercion: soft power (Nye, 2009). The further study of (intangible) smart power and its macro-micro workings within IPP, a wicked problem in itself, will inevitably compel greater cooperation between PAM and IR theorists. This will move Global Governance a step forward from normative vision towards positive reality. Onward PAM-IR — the Inter-Discipline!

\section{References}

Adler, E. (1997). Seizing the middle ground: Constructivism in world politics. European Journal of International Relations, 3(3), 319-363.

Agranoff, R., \& McGuire, M., \& Silivia, S. (2013). Governance, networks and intergovernmental systems. In E. Araral, S. Fritzen, M. Howlett, M. Ramesh, and X. Wu (Eds.), Routledge handbook of public policy (pp. 361-373). New York: Routledge.

Aligica, P. D., \& Boettke, P. J. (2009). Challenging institutional analysis and development: The Bloomington School. London: Routledge.

Anonymous. (2011). The future of public administration in 2020: The spirit of Minnowbrook 2011. Journal of Public Administration Research and Theory (JPART), Special Issue III.

Anderson, T. L., \& McChesney, F. S. (Eds.). (2003). Property rights: Cooperation, conflict and law. New Jersey: Princeton University Press.

Andrews, C. J. (2007). Rationality in policy decision making. In F. Fischer, G. J. Miller and M. S. Sidney (Eds.), Handbook of public policy analysis: Theory, politics and methods (pp. 43-62). Boca Raton: CRC Press.

\footnotetext{
15 (1) self-organization (natural consequence of interaction between simple agents); (2) adaptation (changes made by agents in response to other participants, environmental conditions or emergent system characteristics); (3) path-dependency (tendency for systems to lock into particular behaviours early due to environmental conditions, nature of agents and early interactions); (4) emergence (creation of new properties at higher level of abstraction that cannot be predicted based on antecedent actions or component elements of phenomena); and (5) bifurcation (dynamic to illustrate structures in semi-equilibrium which collapsed into disorder before adopting a new form and equilibrium state from spontaneous self-organization) (Rhodes, Murphy, Muir, \& Murray, 2011, pp. 14-15).
} 
Axelrod, R. (1984). The evolution of cooperation. New York: Basic Books.

Aucoin, P. (1990). Administrative reform in public management: Paradigms, principles, paradoxes and pendulums. Governance: An International Journal of Policy and Administration, 3(2), 117-118.

Barnett, M., \& Sikkink, K. (2008). From international relations to global society. In C. Reus-Smit and D. Snidal (Eds.), The Oxford handbook of international relations (p. 65). Oxford: Oxford University Press.

Barkin, S., \& Cronin, B. (1994). The state and the nation: Changing norms and the rules of sovereignty in international relations. International Organization, 48, 107-130.

Bathlet, H., \& Gluckler, J. (2011). The relational economy: Geographies of knowing and learning. Oxford: Oxford University Press.

Bauer, H., \& Brighi, E. (Eds.). (2009). Pragmatism in international relations. Oxon: Routledge.

Bennington, J., \& Moore, M. H. (2011). Public value: Theory and practice. Basingstoke: MacMillan Palgrave.

Bennett, C. J., \& Howlett, M. (1992). The lessons of learning: Reconciling theories of policy learning and policy change. Policy Sciences, 25(3), 275-294.

Birkland, T. A. (1998). Focusing events, mobilization, and agenda setting. Journal of Public Policy, 18(1), 53-74.

Birdsall, N., \& Fukuyama, F. (2011). The post-Washington Consensus: Development after the crisis. Foreign Affairs, 90(2), Retrieved from http://www.foreignaffairs.com/articles/67456/nancy-birdsall-and-francis-fukuyama/the-post-washington -consensus

Bourgon, J. (2008). Reclaiming public administration. Ethos, 4, 5-9.

Bourgon, J. (2010). Serving beyond the predictable. Ethos, 7, 5-11.

Bourgon, J. (2011a). The new synthesis: Preparing government for challenges of the 21st century. Ethos, 10, 14-20.

Bourgon, J. (2011b). A new synthesis of public administration: Serving the 21 st century. Montreal McGill-Queen's University Press.

Braun, D. (1999). Interests or Ideas? An overview of ideational concepts in public policy research. In D. Braun and A. Busch (Eds.), Public policy and political ideas (pp. 11-29). Cheltenham: Edward Elgar.

Buchanan, J. M., \& Tullock, G. (1962). The Calculus of consent. Ann Arbor: University of Michigan Press.

Butler, B. E. (2013). "Obama” pragmatism in international relations: Appropriate or appropriation? In S. J. Ralston (Ed.), Philosophical pragmatism and international relations: Essays for a bold new world (pp. 159-176). Landham, MD: Lexington Books.

Carlsnaes, W. (2002). Foreign policy. In W. Carlsnaes, T. Risse \& B. A. Simmons (Eds.), Handbook of International Relations (pp. 331-49). London: Sage Publications.

Carr, E. H. (1946). The twenty years crisis. London: Macmillan.

Chhotray, V., \& Stoker, G. (2009). Governance theory and practice: A cross disciplinary approach. Basingstoke: Palgrave MacMillan.

Choi, Y. J., \& Caporaso, J. A. (2002). Comparative regional integration. In W. Carlsnaes, T. Risse \& B. A. Simmons (Eds.), Handbook of international relations (pp. 480-99). London: Sage Publications.

Clemens, E. S., \& Cook, J. M. (1999). Politics and institutionalism: Explaining durability and change. Annual Review of Sociology, 25, 441-466.

Clark, I. (1999). Globalization and international relations theory. Oxford: Oxford University Press.

Cohen, B. J. (2002). International finance. In W. Carlsnaes, T. Risse \& B. A. Simmons (Eds.), Handbook of international relations (pp. 429-47). London: Sage Publications.

Cohen, M., March, J., \& Olsen, J. (1972). A garbage can model of organizational choice. Administrative Science Quarterly, 17(1), $1-25$.

Crabb, C. V Jr. (1989). American diplomacy and the pragmatic tradition. London: Louisana State University Press.

Coase, R. (1997). Nature of the firm. Economica, 4(16), 386-405.

Coase, R. (2013). The institutional structure of production. In C. Menard and M. M. Shirley (Eds.), Handbook of new institutional economics (pp. 31-40). Heidelberg: Springer.

Cooper, H. (2010). Research synthesis and meta-analysis. CA: Sage.

Cox, R. W. (1981). Social forces, states and world orders: Beyond international theory. Millennium Journal of International Studies, 10(2), 126-155.

Cox, R. W. (1983). Gramsci, hegemony, and international relations: An essay in method. Millennium Journal of International Studies, 12, 162-175. 


\section{VALUE OF PUBLIC ADMINISTRATION MANAGEMENT TO INTERNATIONAL RELATIONS}

Dator, J., Pratt, D., \& Seo, Y. (2006). Fairness, globalization and public institutions: East Asia and beyond. Hawaii: University of Hawaii Press.

de Felice, D., \& Obino, F. (2012). Editors' introduction: Weaving the theories and practices in international relations. Millennium: Journal of International Studies, 40(3), 431-437.

Denhardt, R. B., \& Denhardt, J. V. (2007). The New Public Service: Serving not Steering. New York: M.E. Sharpe.

Dennard, F. L., Richardson, K. A. \& Morçöl, G. (Eds.). (2008). Complexity and policy analysis: Tools and concepts for designing robust policies in a complex world. Goodyear, Ariz: ISCE.

Denhardt, R. B., \& Denhardt, J. V. (2007). The new public service: Serving not steering. New York: M.E. Sharpe.

Der Derian, J. (1987). On diplomacy: The genealogy of western estrangement. London: Blackwell.

De Soto, H. (2001). The mystery of capital: Why capitalism triumphs in the west and fails everywhere else. New York: Basic Books.

Dessler, D. (1989). What's at stake in the agent-structure debate? International Organization, 43(3), 441-473.

Doyle, M. (1986). Liberalism in world politics. American Political Science Review, 80(4), 1151-169.

Duffield, J. S. (2006). International security institutions: Rules, tools, schools or fools? In R. A.W. Rhodes, Sarah A. Binder, and Bert A. Rockman, (Eds.), The Oxford handbook of political institutions (pp. 633-653). Oxford: Oxford University Press.

Dunleavy, P. (1994). The globalization of public services production: Can government be "best in world"? Public Policy and Administration, 9(2), 36-64.

Dunlop, C. (2013). Epistemic communities. In E. Araral, S. Fritzen, M. Howlett, M. Ramesh and X. Wu (Eds.), Routledge handbook of public policy (pp. 229-243). New York: Routledge.

Edkins, J. (1999). Post-structuralism and international relations: Bringing the political backin. Colorado: Lynne Rienner.

Epstein, D., \& O’Halloran, S. (1999). Delegating powers. New York: Cambridge University Press.

Evans, M., \& Davies, J. (1999). Understanding policy transfer: A multi-level, multi-disciplinary perspective. Public Administration, 77(2), 361-385.

Farazmand, A. (1999). Globalization and public administration. Public Administration Review, 59(6), 509-522.

Finnemore, M. (1996). National interest in international society. Ithaca: Cornell University Press.

Finkelstein, L. S. (1995) What is global governance. Global Governance, 1(3), 367-372.

Florini, A. (2006). International NGOs. In R. A. W. Rhodes, S. A. Binder, and B. A. Rockman, (Eds.), The Oxford handbook of political institutions (pp. 673-92). Oxford: Oxford University Press.

Frederickson, G., \& Smith, K. B. (2003). The public administration theory primer. Colorado: Westview Press.

Frederickson, H. G. (2005). Whatever happened to public administration? Governance, governance everywhere. In E. Ferlie, L. E. Lynn Jr. and C. Pollitt (Eds.), The Oxford handbook of public management (p. 288). New Yiork: Oxford University Press.

George, J. (1994). Discourses of global politics: A critical (re)introduction to international relations. Colorado: Lynne Rienner.

Geva-May, I. (2001). When the motto is "till death do us part": The conceptualization and the craft of termination in the public policy cycle. International Journal of Public Administration, 24(3), 263-288.

Giddens, A. (1984). The constitution of society: Outline of the theory of structuration. Cambridge: Polity Press.

Gilady, L., \& Russett, B. (2002). Peace-making and conflict resolution. In W. Carlsnaes, T. Risse \& B. A. Simmons (Eds.), Handbook of International Relations (pp.392-408). London: Sage Publications.

Goldman, L. (2013). Getting beyond international relations theory. In S. J. Ralston (Ed.), Philosophical pragmatism and international relations: Essays for a bold new world (pp. 15, 65). Landham, MD: Lexington Books.

Goldstein, J., \& Keohane, R. (1993). Ideas and FP: An analytical framework. In J. Goldstein and R. O. Keohane (Eds.), Ideas \& foreign policy: Beliefs, institutions, and political change (pp. 3-30). Ithaca: Cornell University.

Gottlieb, R. S. (1981). The contemporary critical theory of Jürgen Habermas. Ethics, 91(2), 280-295.

Gray, J. (1998). False dawn: The delusions of global capitalism. London: Grata.

Haas, P. M. (1992). Epistemic communities and international policy coordination. International Organization, 46(1), 1-35.

Hayes, M. (2013). Incrementalism. In E. Araral, S. Fritzen, M. Howlett, M. Ramesh, and X. Wu (Eds.), Routledge handbook of public policy (pp. 287-298). New York: Routledge.

Hawkins, K., \& Thomas, J. M. (1989). Making policy in regulatory bureaucracies. In K. Hawkins and J. M. Thomas (Eds.), Making regulatory policy (pp. 3-30). Pittsburgh: University of Pittsburgh Press.

Holcombe, R. G. (2005). Public sector economics: The role of government in the American economy. NY: Prentice Hall.

Héritier, A. (2003). New modes of governance in Europe: Increasing political capacity and policy effectiveness? In T. A. Börzel and R. Cichowski, (Eds.), The state of the European Union: Law, politics, and society (pp. 105-126). NY: Oxford University Press. 
Hall, P. A., \& Taylor, R. C. R. (1996). Political science and the three new institutionalisms. Political Studies, 44, $936-957$.

Harris, C. (2010). Research synthesis and meta-analysis. CA: Sage.

Haveri, A. (2006). Complexity in local government change: Limits to rational reforming. Public Management Review, 8(10), 31-46.

Held, D. (1995). Democracy and the global order: From the modern state to cosmopolitan governance. Cambridge: Cambridge University Press.

Heclo, H. (1978). Issue networks and the executive establishment. In A. King (Ed.), The new American political system (pp. 87-124). Washington D.C.: American Enterprise Institute for Public Policy Research.

Hendriks, C. (2013). Policy evaluation and public participation. In K. Hawkins and J. M. Thomas (Eds.), Making regulatory policy (pp. 3-30). Pittsburgh: University of Pittsburgh Press.

Howlett, M. (2007). Analyzing multi-actor, multi-round public policy decision-making processes in government: Findings from five Canadian cases. Canadian Journal of Political Science, 40(3), 659-684.

Howlett, M. (2009). Policy analytical capacity and evidence-based policy-making: Lessons from Canada. Canadian Public Administration, 52(2), 153-175.

Howlett, M., Perl, A., \& Ramesh, M. (2009). Studying public policy: Policy cycles and policy subsystem. Toronto: Oxford University Press.

Higgott, R. (2006). International political institutions. In R. A. W. Rhodes, S. A. Binder, and B. A. Rockman, (Eds.), The Oxford handbook of political institutions (pp. 611-32). Oxford: Oxford University Press.

Ingraham, P. W., \& Lynn, L. E. (2004). The art of governance. Washington: Georgetown University Press.

Jones, B., \& Thomas, H. (2013). Bounded rationality and public policy decision-making. In E. Araral, S. Fritzen, M. Howlett, M. Ramesh, and X. Wu (Eds.), Routledge handbook of public policy (pp. 273-286). New York: Routledge.

Jupille, J., \& Caporaso, J. A. (1999). Institutionalism and the European Union: Beyond international relations and comparative politics. Annual Review of Political Science, 2(9), 429-444.

Kadelbach, S. (2009). From public international law to international public law: A comment on the "public authority" of international institutions and the "publicness' of their law". In A. von Bogdandy, R. Wolfrum, J. von Bernstorff, P. Dann, and M. Goldmann (Eds.), The exercise of public authority by international institutions: Advancing international institutional law (pp. 33-49). Heidelberg: Springer.

Katzenstein, P. (Ed.). (1996). The culture of national security. New York: Columbia University Press.

Kay, A. (2013). Policy trajectories and legacies: Path dependency revisited. In E. Araral, S. Fritzen, M. Howlett, M. Ramesh, and

X. Wu (Eds.), Routledge handbook of public policy (pp. 462-472). New York: Routledge.

Keohane, R. (Ed.). (1986). Neorealism and its critics. New York: Columbia University Press.

Kettl, D. (1993). Sharing power: Public governance and private markets. Washington D. C.: Brookings Institution.

Kingdon, J. W. (1995). Agendas, alternatives and public policies. Boston: HarperCollins College Publishers.

Kjaer, A. M. (2004). Governance. Cambridge: Polity Press.

Klinger, D. E. (2004). Globalization, governance and the future of public administration: Can we make sense out of the fog of rhetoric surrounding the terminology? Public Administration Review, 64(6), 737-43.

Krasner, S. D. (1983). Structural causes and regime consequences: Regimes as intervening variables. In S. D. Krasner (Ed.), International regimes (pp. 1-22). New York: Cornell University Press.

Lejano, R. P. (2013). Post-positivism and the policy process. In E. Araral Jr., M. Howlett, M. Ramesh and X. Wu (Eds.), Routledge handbook of public policy (pp. 98-112). New York Routledge.

Little, R. (2009). Preface. In H. Bauer \& E. Brighi (Eds.), Pragmatism in international relations (pp. xii-xiii). Oxon: Routledge.

Lindblom, C. E. (1959). The science of muddling through. Public Administration Review, 19(2), 79-88.

Margetts, H. (2005). Virtual organisations. In E. Ferlie, L. E. Lynn Jr. and C. Pollitt (Eds.), The Oxford handbook of public management (pp. 305-325). New York: Oxford University Press.

Martin, L. L. (2006). International economic institutions. In R. A. W. Rhodes, S. A. Binder, and B. A. Rockman (Eds.), The Oxford handbook of political institutions (pp. 654-72). Oxford, Oxford University Press.

Marsh, D., \& Smith, M. (2000). Understanding policy networks: Towards a dialectical approach. Political Studies, 48, 4-21.

Maskin, E. (2010). Mechanism design: How to implement social goals. Retrieved April 20, 2014, from http://www.nobelprize.org/nobel_prizes/economic-sciences/laureates/2007/maskin_lecture.pdf

Maxfield, S. (2002). International development. In W. Carlsnaes, T. Risse, and B. A. Simmons (Eds.), Handbook of International Relations (pp.462-79). London: Sage Publications. 
McConnell, A. (2013). Learning from Success and Failure? In K. Hawkins and J. M. Thomas (Eds.), Making regulatory policy (pp. 3-30). Pittsburgh: University of Pittsburgh Press.

McGinnis, M. (Ed.). (1999). Poly centricity and local public economies: Readings from workshop in political theory and policy analysis. Ann Arbour: University of Michigan Press.

McGinnis, M. (2011). An introduction to IAD and the language of the Ostrom workshop: A simple guide to a complex framework. Policy Studies Journal, 39(1), 169-183.

Mendez, R. P. (1992). International public finance: A new perspective on global relations. Oxford: Oxford University Press.

Milner, H. V. (2002). International trade. In W. Carlsnaes, T. Risse \& B. A. Simmons (Eds.), Handbook of international relations (pp. 480-99). London: Sage Publications.

Minogue, M. (2001). The Internationalization of New Public Management. In W. McCourt and M. Minogue (Eds.), The internationalization of public management: Reinventing the third world state (pp. 1-19). Cheltenham: Edwin Elgar.

Mitchell, R. B. (2002). International Environment. In W. Carlsnaes, T. Risse, and B. A. Simmons (Eds.), Handbook of international relations (pp. 500-16). London: Sage Publications.

Moore, M. H. (1998). Creating public value: Strategic management in government. MA: Harvard University Press.

Morçöl, G. (2002). A new mind for policy analysis: Toward a post-newtonian and post-positivist epistemology and methodology. London: Praeger.

Morcol, G. (2012). A complexity theory for public policy. New York: Routledge.

Morgenthau, H. (1985). Politics among nations: The struggle for power and peace (6th ed.). New York: Knopf.

Muller, H. (2002). Security cooperation. In W. Carlsnaes, T. Risse \& B. A. Simmons (Eds.), Handbook of international relations (pp. 369-91). London: Sage Publications.

Nagel, S. S. (Ed.). (2000). Handbook of global international policy. New York: Marcel Dekker.

Nye, J. (2009). Get smart: Combining hard and soft power. Foreign Affairs, Jul/Aug.

O'Flynn, J. (2007). From new public management to public value: Paradigmatic change and managerial implications. The Australian Journal of Public Administration, 66(3), 353-366.

Osborne, D., \& Gaebler, T. (1993). Reinventing government: How the entrepreneurial spirit is transforming the public sector. New York: Plume.

Ostrom, E. (1990). Governing the commons: The evolution of institutions for collective action. New York: Cambridge University Press.

Ostrom, E., Schroeder, L., \& Wynne, S. (1993). Institutional incentives and sustainable development: Infrastructure policies in perspective. Colorado: Westview Press.

Osborne, S. P. (2006). The new public governance. Public Management Review, 8(3), 377-387.

O'Toole, L. J. (2000). Research on policy implementation: Assessment and prospects. Journal of Public Administration Research and Theory, 10(2), 263-288.

Palumbo, D. J. (1987). The politics of program evaluation. Beverly Hills: Sage.

Peters, G. (1996). The future of governing: Four emerging models. Lawrence: University Press of Kansas.

Peters, G. (1998). Policy networks: Myth, metaphor and reality. In D. Marsh (Ed.), Comparing policy networks (pp. 21-32). Buckingham: Open University Press.

Powell, R. (1994). Anarchy in international relations theory: The neorealist-neoliberal debate. International Organization, 48(2), 313-344.

Raab, J., \& Kenis, P. (2007). Taking stock of policy networks: Do they matter? In F. Fischer, G. J. Miller and M. S. Sidney (Eds.), Handbook of public policy analysis: Theory, politics and methods (pp. 187-200). Boca Raton: CRC Press.

Rhodes, R. A. W. (2000). Governance and Public Administration. In J. Pierre (Ed.), Debating governance: Authority, steering and democracy (pp. 54-56). Oxford: Oxford University Press.

Ralston, S. J. (Ed.). (2013). Philosophical pragmatism and international relations: Essays for a bold new world. Plymouth: Lexington Books.

Raustiala, K., \& Slaughter, A. M. (2002). International law, international relations and compliance. In W. Carlsnaes, T. Risse and B. A. Simmons (Eds.), Handbook of international relations (pp. 538-558). London, Sage.

Rhodes, M. L., Murphy, J., Muir, J., \& Murray, J. A. (2011). Public management and complexity theory: Richer decision-making in public service. New York: Routledge.

Ruggie, J. G. (1998). What makes the world hang together: Neo-utilitarianism and the social constructivist challenge. International Organization, 52(4), 855-885. 


\section{VALUE OF PUBLIC ADMINISTRATION MANAGEMENT TO INTERNATIONAL RELATIONS 861}

Sabatier, P. A. (1986). Top-down and bottom-up approaches to implementation research: A critical analysis and suggested synthesis. Journal of Public Policy, 6, 21-48.

Sabatier, P. A. (1988). An advocacy coalition framework of policy change and the role of policy-oriented learning therein. Policy Sciences, 21(2/3), 129-168.

Schmitz, H. P., \& Sikkink, K. (2002). International human rights. In W. Carlsnaes, T. Risse, and B. A. Simmons (Eds.), Handbook of international relations (pp. 517-37). London: Sage Publications.

Schmidt, V. (2008). Discursive institutionalism: The explanatory power of ideas and discourse. Annual Review of Political Science, 11, 303-326.

Schneider, A. (2013). Policy design and transfer. In E. Araral, S. Fritzen, M. Howlett, M. Ramesh, and X. Wu (Eds.), Routledge Handbook of Public Policy (pp. 217-228). New York: Routledge.

Schaferhoff, M., Campe, S., \& Kaan, C. (2009). Transnational public-private partnership in international relations: Making sense of concepts, research frameworks and results. International Studies Review, 11(3), 451-474.

Shafritz, J. M., Hyde , A. C., \& Parkes, S. J. (2008). Classics of public administration. CA: Wadsworth.

Sen, A. (1977). Rational fools. Philosophy and Public Affairs, 6(4), 317-344.

Stigler, G. (1962). The economic theory of regulation. Bell Journal of Economics and Management Science, 3, 3-18.

Stigliz, J. (2014). Post Washington Consensus Consensus. The Institute for Policy Dialogue. Retrieved February 20, 2014, from http://policydialogue.org/files/events/Stiglitz_Post_Washington_Consensus_Paper.pdf

Smith, S., \& Booth, K., \& Zalewski, M. (1996). International theory: Positivism and beyond. Cambridge: Cambridge University Press.

Smouts, M. C. (1998). The proper use of governance in international relations. UNESCO.

Snellen, I. (2005). E-government: A challenge for public management. In E. Ferlie, L. E. Lynn Jr. and C. Pollitt (Eds.), The Oxford handbook of public management (pp. 398-421). New York: Oxford University Press.

Stoker, G. (1998). Governance as theory: Five propositions. UNESCO.

Simon, S., \& Tay, C. (2010). Asia alone: The dangerous post-crisis divide from America. Singapore: John Wiley \& Sons.

Taylor, F. (1912). Scientific Management. In J. M. Shafritz and A. C. Hyde (Eds.), Classics of public administration (6th ed.) (pp. 36-8). Boston, Thomson Wadsworth.

Thucydides. (1910). The Peloponnesian war. London, J. M. Dent; New York, E. P. Dutton.

True, J. L., Jones, B. D., \& Baumgartner, F. R. (1999). Punctuated-equilibrium theory: Explaining stability and change in American policymaking. In P. A. Sabatier (Ed.), Theories of the policy process (pp. 97-115). Boulder: Westview Press.

Vezke, I. (2010). International Bureaucracies from a political science perspective-Agency, authority and international institutional law. In A. von Bogdandy, R. Wolfrum, J. von Bernstorff, P. Dann and M. Goldmann (Eds.), Developing the Publicness of public international law: Towards a legal framework for global governance activities (pp. 3-32; 33-49; 67-98).

von Bogdandy, A., Dann, P., \& Goldmann, M. (2008). Developing the publicness of public international law: Towards a legal framework for global governance activities. German Law Journal, 9(11), 1375-1400.

Vigoda, E. (2002). From responsiveness to collaboration: Governance, citizens, and the next generation of public administration. Public Administration Review, 62(5), 527-540.

Vygotsky, L. (1978). Social development theory. Retrieved November 1, 2013, from http://www.k-state.edu/musiceducation/eportfolio/cexum/images/Images\%20File\%20for\%20Eportfolio/Lev\%20Vygotsky\% 20Social\%20Development\%20Theory\%20Class\%20Hand\%20Out.pdf

Walker, R. B. J. (1992). Inside/outside: International relations as political theory. Cambridge: Cambridge University Press.

Waltz, K. (1959). Man, the state and war. New York: Columbia University Press.

Waltz, K. (1979). Theory of international politics. McGraw Hill.

Weaver, R. K., \& Rockman, B. A. (1993). When and how do institutions matter? In R. K. Weaver and B. A. Rockman (Eds.), Do institutions matter? Government capabilities in the United States and abroad (pp. 445-461). Washington, D.C.: Brookings Institutions.

Weber, M. (1922). Bureaucracy. In J. M. Shafritz and A. C. Hyde (Eds.), Classics of public administration (6th ed.) (pp. 43-48). Boston, Thomson Wadsworth.

Weber, E. T. (2013). On pragmatism and international relations. In S. J. Ralston (Ed.), Philosophical pragmatism and international relations (pp. 36-43). Lanham, MD: 1EXINGTON Books.

Wendt, A. (1987). The agent-structure problem in international relations theory. International organization, 41(Summer), 35-73. 


\section{VALUE OF PUBLIC ADMINISTRATION MANAGEMENT TO INTERNATIONAL RELATIONS}

Wendt, A. (1992). Anarchy is what states make of it: The social construction of power politics. International Organization, 46, 391-425.

Wendt, A. (1999). Social theory of international politics. Cambridge: Cambridge University Press.

White, L. D. (1926). Introduction to the study of public administration. Macmillan, New York.

Williamson, O. (2013). The transaction cost economics project: The theory and practice of the governance of contractual relations. London: Edward Elgar Pub.

Wilson, W. (1887). The Study of Administration. In J. M. Shafritz and A. C. Hyde (Eds.), Classics of public administration (6th ed.) (pp. 16-27). Boston, Thomson Wadsworth. 